\title{
The Impact of Minimum Wage on Female Employment in Japan ${ }^{1}$
}

\author{
Daiji Kawaguchi ${ }^{2}$ \\ Institute of Policy and Planning Sciences, University of Tsukuba \\ and \\ Ken Yamada \\ Institute of Social and Economic Research, Osaka University
}

January 2004

\footnotetext{
${ }^{1}$ The Japan Panel Survey of Consumers (Shōhi Seikatsu ni Kansuru Paneru Chōsa), published by The Institute for Research on Household Economics (Kakei Keizai Kenkyūsho), 1-3-13 Hirakawacho, Chiyoda-ku, Tokyo 102-0093, Japan, is used in this study. We thank the Institute for providing the data. Due to a confidentiality agreement with the Institute, these data cannot be released. We thank the seminar participants at the Kansai Institute of Social and Economic Research for their comments.

${ }^{2}$ Corresponding Author: Tennodai 1-1-1, Tsukuba, Ibaraki, 305-8573, Japan; Tel: (81)-29-853-7432; Fax: (81)-29-855-3849; E-Mail:kawaguch@sk.tsukuba.ac.jp
} 


\begin{abstract}
The statutory minimum wage in Japan is revised every year and increases by almost the same amount across prefectures, regardless of the disparity in the wage distribution across prefectures. Due to this feature of minimum wage setting, the minimum wage cuts into the wage distribution deeply in rural Japan. We examine the impact of the minimum wage on employment, focusing on middle-aged women, who are known to be typical, low-wage workers in Japan. The results, based on a panel estimation, suggest that minimum wage has a large impact on employment; the workers whose current wage is below the revised minimum wage are about 20 percentage points less likely to be employed in the following year than the low-wage workers who are not affected by the revision of the minimum wage.
\end{abstract}

Keywords: Minimum Wage, Employment, Wage, Panel Data, Japan JEL Classification Code: J23, J38, J88 


\section{Introduction}

This paper estimates the effect of minimum wage on employment among middle-aged women in Japan. The minimum wage in Japan has been set at a very low level compared with its average wage for a long time. For example, the ratio of minimum wage to median wage ${ }^{1}$ in 1997 was 0.31 in Japan, whereas it was 0.57 in France, 0.49 in the Netherlands, 0.46 in New Zealand, 0.40 in Canada, 0.38 in the US, and 0.32 in Spain (Table 2.3 in OECD [1998]). This considerably low level of effective minimum wage has discouraged researchers' interest, and there has been virtually no research directly examining the effect of the minimum wage on employment in Japan. However, we should doubt the effect of minimum wage on the employment of middle-aged female workers, particularly in rural areas, due to the following reasons. First, the male-female wage gap in Japan is larger than it is in other developed countries. Second, while the wage distributions are heterogeneous across Japan's prefectures, the regional minimum wage is not very heterogeneous, for egalitarian purposes. Third, current ongoing deflation and its associated nominal wage decline presumably make the minimum wage more likely to bind. These economic conditions and the institution of minimum wage setting in Japan may cause a more serious bite of minimum wage for subgroups of workers in certain regions. Neumark and Wascher [2004], for example, emphasized the importance of examining the institution of mini-

\footnotetext{
${ }^{1}$ including overtime pay and bonuses
} 
mum wage setting for each country, in addition to looking at the national measure. This research attempts to enact their suggestion.

The disemployment effect of minimum wage has been widely examined in North American and European countries. Early studies attempted to identify the disemployment effect using time series data. However, since the late 1980s, US researchers have used cross-state variations of the minimum wage to identify its disemployment effect. The usage of time series data became unpopular because it is difficult to disentangle the effect of minimum wage from the effect of macro shocks that can be correlated with revisions in the level of the minimum wage. More credit has been given to the results based on state-level panel data that principally have applied a difference in difference (DID) approach to identify the disemployment effect of the minimum wage. In these studies, the state that changed the minimum wage was classified as the treatment group and the other states, whose minimum wages were unchanged, were classified as the control group. A famous example of research that applied DID to identify the disemployment effect was Card and Krueger [1994], while another famous example that used all 50 states was Neumark and Wascher [1992]. As indicated by Card and Krueger [2000] and Neumark and Wascher [2000], there has been heated controversy regarding the existence of the disemployment effect of minimum wage in the US, and we believe it is still fair to say that a definitive conclusion has not been reached.

While US researchers have exploited the existence of state variations in 
the minimum wage to identify its effect on employment, European researchers have struggled to define appropriate treatment and control groups because European countries tend to have uniform, nationwide minimum wage systems. A recent study by Machin et al. [2003] examined the effect of the newly introduced statutory national minimum wage on employment in a low-wage industry, the residential care homes industry. They used the initial average wage of the homes' workers to define the control and treatment groups. The workers in homes whose average wage was originally below the newly adopted minimum wage were classified as the treatment group, and those in homes whose initial average wage was above the minimum were classified as the control group. These researchers found a moderate disemployment effect. Pereira [2003] used the increase of the minimum wage that applied only to workers aged 18 and 19 in 1985 in Portugal to define the control and treatment groups. She found a significant decrease in the employment of these workers, as well as a significant increase in the employment of workers aged 20 to 25 through the substitution effect, using workers aged 30 to 35 as a control group. See Machin and Manning [1997] and Brown [1999] for a review of the literature regarding Europe.

To consider the identification strategy for Japan, we now briefly explain the institution of minimum wage setting in Japan (See Araki [2002] and Sugeno [2002] for further explanations). The Japanese minimum wage is a statutory minimum wage based on the Minimum Wages Law enacted in 1959, which was substantially revised in 1967 . The current law defines two types of 
minimum wage, 1 . regional minimum wages based on collective agreement; and 2. minimum wages based on the study and deliberations of the minimum wage councils. Although the first system assumes that the minimum wage agreed upon by craft-wide or industry-wide bargaining will be extended to non-unionized workers in the same sector, such bargaining does not really exist under the Japanese enterprise union system. Thus, practically speaking, all minimum wages in Japan are currently determined by type 2 . Under this system, the chief of the prefectural labor bureau determines the level of the prefectural minimum wage based on the regional minimum wage councils' deliberations. These deliberations are largely influenced by the "criteria" for the amount of minimum wage increase set by the central minimum wage council annually. The central minimum wage council consists of representatives of public interest (academicians and a retired bureaucrat), employers, and employees. The central council divides all Japanese prefectures into four ranks, based on the actual level of wage within them and the differentials in the cost of living. The central minimum wage council then issues the "criteria" for the amount of minimum wage increase for each rank. Prefectures classified as Rank A set the highest minimum wage; the daily minimum wage was 5514 yen and the hourly minimum wage was 698 yen in 1999 in Tokyo, an increase in 49 yen from the previous year. At the same time, prefectures in Rank D set the lowest minimum wage. For example, the daily minimum wage was 4756 yen and the hourly minimum wage was 595 yen in Miyazaki in the same year and the difference from the previous year was 42 yen for the 
daily minimum. Between 1993 to 1999, which is the sample period for our analysis, the classification of prefectures into ranks changed once, in 1995. In this re-classification, 3 prefectures moved from Rank $\mathrm{C}$ to $\mathrm{B}, 2$ prefectures moved from Rank D to C, and two prefectures moved from Rank B to C (Abe [2001]). Except for this re-classification, each prefecture had been classified into the same rank for every year. Due to the fact that the amount of increase was about one percent of the original minimum wage and the rate of the minimum wage increase was almost homogeneous across prefectures, it is virtually impossible to identify the disemployment effect of the minimum wage based on the variation in the change of minimum wage across prefectures. This fact prohibits us from using DID as an identification strategy in Japan. Prefectural minimum wages are revised every year based on the above procedure and the revised minimum wages take effect beginning on September 30 or October 1 of the same year. ${ }^{2}$

The legal enforcement of the minimum wage is weak in Japan. The prefectural labor bureau is in charge of enforcement and when it detects employers' non-compliance with the minimum wage, they could be responsible for fines up to 20 thousand yen (about 160 US dollars), which is negligible. Employers who violate the minimum wage law have to compensate employees for the difference between the minimum wage and the actual wage. The minimum wage is mostly enforced through public pressure on employers. In particu-

\footnotetext{
${ }^{2}$ There are some exceptional cases in which the revised minimum wage takes effect in the middle of October, but this is very rare.
} 
lar, larger-sized employers would lose their reputations if the public were to notice that they pay less than the minimum wage to their workers.

Facing the difficulty of how to identify the disemployment effect of the minimum wage due to the system of minimum wage setting in Japan, we adopted the methodology proposed by Currie and Fallick [1996] and Yuen [2003]. We compared the change in employment status among those workers whose current wage is below the newly set minimum wage level and those workers whose current wage is above new minimum wage, using panel data of workers. The former group of workers was treated by the minimum wage and other workers were not treated and thus served as a control group. If we find that the former group of workers was less likely to be employed in the following year than those workers in the latter group, we arguably can confirm the disemployment effect of minimum wage. The estimation results point to a large disemployment effect: The average employment rate of the workers treated by the minimum wage was about 20 percent lower than that of the workers who were not treated by the minimum wage. The results are robust against the change in the definition of the control group. The results did not change in the fixed effects estimation, which allowed for time-constant, individual heterogeneity.

To the best of our knowledge, there are three studies that have examined the relationship between minimum wage and wage distribution in Japan. Using a comprehensive current status survey of part-time workers (Pāt Taimu Rōdōsha Sōgō Jittai Chōsa), Abe [2001] examined the wage distribution of 
part-time, female workers in 1990 and 1995 in comparison with the minimum wage set for each prefecture. She concluded that, on average, the level of the minimum wage is set at a low level, so that the minimum wage generally does not bind. However, she found that the prefectural minimum wage tends to bind in rural areas because the average wages in rural area are generally low, while the level of the minimum wage is not so heterogeneous across prefectures. She speculated that the disemployment effect of the minimum wage would be minimal because the minimum wage does not bite the wage distribution. Based on the same data, Kohara [2000] found that the minimum wage cuts into the distribution of wage in rural areas, and Nagase [1997] pointed out that about 50 percent of part-time workers earned less than 100 yen plus the minimum in 1990. The above studies pointed out that the minimum wage in Japan is set at a low level compared with its average wage, but it does cut into the wage distribution in rural areas. None of the above studies, however, have examined the impact of minimum wage on employment.

The rest of the paper is organized as follows. Section 2 outlines the empirical strategy to identify the disemployment effect of minimum wage. Section 3 explains the data. Section 4 reports and discusses results. Section 5 checks the robustness of the results. Section 6 concludes. 


\section{Empirical Models}

We first attempt to examine whether the minimum wage changes the wage distribution. We identify the effect of minimum wage on wage increase among low-wage workers by estimating the following model:

$$
\Delta w_{i t}=\beta_{0}+\beta_{1} \text { bind }_{i t-1}+x_{i t-1} \gamma+u_{i t}, \text { given emp } p_{i t-1}=1,
$$

where $i$ is the index for individuals, $t$ is the index for year, bind $d_{i t-1}$ is the dummy variable indicating the minimum wage treatment (i.e. $m w_{i t-1} \leq$ $\left.w_{i t-1} \leq m w_{i t}\right)$, and $x_{i t-1}$ is the vector of explanatory variables that captures the strength of individual workers' labor market attachment. If the minimum wage affects the wage of low paid workers, $\beta_{1}>0$ is expected.

Second, to identify the disemployment effect of minimum wage using panel data, we estimate the following linear probability model:

$$
e m p_{i t}=\beta_{0}+\beta_{1} \text { bind }_{i t-1}+x_{i t-1} \gamma+u_{i t} \text {, given emp } p_{i t-1}=1 \text {, }
$$

with all the notations the same as before. Although the dependent variable is binary, we adopt the linear probability model because allowing for each worker's fixed effects is easy in the framework of such models. The parameters in this model are consistently estimated via OLS under the assumption that the error term is not correlated with the independent variables. This assumption is violated if those workers belonging to the treatment group (i.e. bind $_{i t-1}=1$ ) have unobserved characteristics that make them more likely to drop off from the labor market than the workers belonging to the control 
group (i.e. bind $_{i t-1}=0$ ). To relax this rather strong assumption, we allow for each worker's heterogeneity by assuming

$$
u_{i t}=c_{i}+v_{i t}
$$

If the independent variables are strictly exogeneous from the composite error term $u_{i t}$, the random effects estimator is the efficient estimator under the assumption that $v_{i t}$ is i.i.d. The fixed effects estimator is a consistent estimator, even when individual time-fixed heterogeneity, $c_{i}$, is correlated with the independent variables. Thus, the fixed effects estimator allows for the possibility that those low-wage workers treated by the minimum wage have a weak, labor market attachment.

The issue of the workers' heterogeneity in the treatment and control groups is also addressed by restricting the control group. To avoid the possibility of comparing very different types of workers to estimate the effect of minimum wage, we restricted our analysis sample to low-wage workers (i.e., those workers whose current wage is less than 110 percent of the current minimum wage). By comparing the estimated results from full and restricted samples, we can roughly learn how the heterogeneity of workers affected our estimates. It is also worth mentioning the timing of the minimum wage revision and the time of survey. The revised minimum wage takes effect on either September 30 or October 1, depending on the prefecture, while the survey takes place sometime in October. Thus, when (1) is estimated as is, we implicitly assume that the revision of the minimum wage that takes place 
at the beginning of October affects the wage that is reported in October.

\section{Data}

This study uses the Japan Panel Survey of Consumers (JPSC) collected by the Institute of Household Economics (Kakei Keizai Kenkyusho). This survey is based on a national, representative sample of women who were between the ages of 24 and 34 in 1993, which was the starting year of the survey. ${ }^{3}$ The survey included 1,500 women at the beginning and added 500 women in 1997. The survey has been implemented between October 1 and October 31 of every year. We pooled all the data between 1993 to 1999 and we obtained special permission to use the data set with each respondent's prefecture code. This prefecture code enabled us to match a prefectural minimum wage to each respondent. The information on prefectural minimum wage was obtained from The Pandect of Minimum Wage Determination (Saitei Tingin Kettei Yōran), which is published every year. We disregarded the industrial minimum wage because the industry code recorded in the JPSC is too rough to match with the industrial minimum wage, which is defined with very detailed industry classifications.

The construction of our analysis sample is illustrated in Table 1. We restricted our analysis sample to those workers who received their wage on an hourly or daily basis. Our estimation also required observations for two consecutive years; 1438 observations remained after this sample restriction.

\footnotetext{
${ }^{3}$ Information on their family members was also collected.
} 
This basic analysis sample is called the full sample hereafter. We further restricted our sample to the workers whose current wage was below 110 percent of the ongoing minimum wage to include only low-wage workers in the sample. This restriction reduced the sample size to 236 and we call this sample restricted sample A hereafter. To exclude those workers who were temporarily classified as low-wage workers, we further restricted our sample to workers whose wage was less than 110 percent of the current wage for two years or more during the sample period. This additional restriction reduced the sample size to 148, and we call this sample restricted sample A' hereafter. This restricted sample $A^{\prime}$ is used to estimate the random and fixed effects models. Restricted sample A includes those workers whose wage were below the current minimum wage. We further restricted our sample to exclude these workers and call the sample restricted sample B. This sample includes 148 observations. The observations that belonged to restricted sample B for two years or more are called restricted sample B' and its sample size is 96 . The restricted samples B and B' are used in the robustness check.

The descriptive statistics for the analysis sample appear in Table 2. Column (1) reports the means of the dependent and independent variables of the observations for the control group in the full sample. Columns (2) and (3) report the means of variables for the control group in restricted samples A and B respectively. Comparing the columns for the control group with column (4), which is the column for the treatment group, we notice that the individual characteristics are similar between the control and treatment 
groups in terms of marital status, the number of children, and age. Workers in the treatment group have slightly more years of job tenure, but slightly fewer years of job experience. Workers in the control group of the full sample naturally had more extensive higher educational backgrounds than workers in the treatment group; however, workers in the control group in the restricted samples A and B had slightly less educational background than the workers in the treatment group. There are some individuals who were in the sample in year $t-1$ but not in year $t$ because they did not respond to the interview or had missing information. This sample attrition may have caused attrition bias in our estimation. We calibrated the seriousness of the attrition bias by examining the characteristics of attritors in year $t-1$. The sample means for these attritors are tabulated in Column (5). Comparing the sample means for Columns (1) and (5), we arguably can conclude that these attritors were not significantly different from the non-attritors in terms of observed characteristics in year $t-1$.

Figures 1 to 4 draw the time series of the ratio of minimum wage to average wage in each prefecture. We used the Basic Survey on Wage Structure by the Ministry of Health, Labor, and Welfare to obtain the national average of hourly rate of pay among female part-time workers (Table 4 of RōdōHōrei-Kyōkai [Each Year]). Figure 1 is for prefectures identified as Rank A in the minimum wage classification, which are urban prefectures. ${ }^{4}$ For two prefectures among those in Rank A, we can observe that the minimum wage

\footnotetext{
${ }^{4}$ The rank classification of each prefecture is based on the classification in 1993.
} 
ratio increased over time. Figures 2, 3, and 4 are for prefectures classified as Ranks B, C, and D respectively. We can observe that the minimum wage ratio to average wage increased over time. The ratio varied by a large amount among prefectures in Ranks C and D. For many prefectures in Ranks C and $\mathrm{D}$, the ratio exceeded 0.75 . This finding suggests that the minimum wage is set relatively high in those prefectures classified as Ranks C and D, which are rural prefectures. Thus, we can speculate that disemployment due to the minimum wage would be serious in rural areas if there is any disemployment effect.

\section{Results}

\subsection{The impact of minimum wage on wage distribution}

The estimation results for the effects of minimum wage on the change of wage appears in Table 3. The regression results based on the full sample, which are reported in column (1), indicate that those workers treated by the increase in minimum wage experienced about a 4 percentage points higher wage growth rate than the workers in the control group. The coefficient is not precisely estimated, perhaps because only 18 observations are treated in year $t-1$. In addition, some of the treated workers were dropped due to the disemployment effect of the minimum wage hike. Among the 18 cases that were treated by the minimum wage, only 10 are included in the sample of 963 workers. Regardless of this statistical insignificance, the size of the 
coefficient is not negligible if it is taken seriously. ${ }^{5}$

Columns (2) and (3) report the estimation results based on the restricted samples $A$ and $B$ respectively. We again found the positive effect of the minimum wage treatment on wage growth, but the estimated effects are not statistically significant. The estimated effects are 0.017 and 0.023 respectively and these effects are large, considering the fact that the minimum wage is raised by 1 percent annually. The statistical insignificance is not that surprising, considering the fact that only 10 workers were treated by the minimum wage among 151 and 106 observations respectively.

These results indicate that the minimum wage in Japan does not necessarily form the wage floor among low-wage workers. This is either because of weak law enforcement of the minimum wage or the fact that a very small number of workers is affected by the minimum wage in the sample because those workers whose wage was potentially treated by the minimum wage were dropped from the sample due to their possible disemployment. Thus, the fact that the minimum wage treatment does not have a statistically significant effect on the wage distribution is not so discouraging.

\subsection{The impact of minimum wage on employment}

Now we move onto the disemployment effect of minimum wage. Table 4 reports the estimated impact of the minimum wage on employment in the

\footnotetext{
${ }^{5}$ We also tried the specification that includes $w_{i, t-1}$ as an explanatory variable to be consistent with human capital theory as in Neumark and Taubman [1995], but the results did not change in an essential way.
} 
following year. The results in Column (1) indicate that those whose wage is below the revised minimum wage are 10 percentage points less likely to be employed in the following year. The estimated results are not statistically significant, however. To apply the panel estimation methods, we restricted the sample to those individuals that were observed for two years or more and this sample restriction reduced the sample size to 1213 . The results of the OLS estimation appear in Column (2). The size of the coefficient shrinks, probably due to the fact that the treatment group and the control group became more homogeneous in terms of their degree of labor market attachment due to the further sample restriction. The results of the random and fixed effects estimations appear in Columns (3) and (4) respectively. All the results indicate that we cannot reject the null hypothesis that the minimum wage does not affect employment in the following year due to the large standard error around the estimated coefficients.

The estimation results reported above may be criticized because the control group includes those workers who received wages far above the minimum wage. If workers with a high wage have a stronger attachment to employment, the above estimations overestimate the adverse effect of minimum wage on employment. To address this possible criticism, we restrict our sample to those individuals whose current wage is below 110 percent of the current minimum wage to include only low-wage workers in the control group. Notice that those workers whose current wage is below the current minimum wage also are included in this control group. The results of the estimation based 
on this restricted sample A appears in Table 5. For the OLS and random effects estimation, we obtain the coefficient around -0.15 with a standard error of 0.08 or 0.09 . For the fixed effects estimation, we obtain the coefficient of -0.23 with a standard error of 0.13 . We marginally reject the null hypothesis of no effect of the minimum wage on employment. This estimated coefficient implies that those workers who are treated by the minimum wage are about 15 or 23 percentage points less likely to be employed in the following year. The difference in the results from Table 4 implies that those workers with a higher current wage have less attachment to employment. When those workers with the minimum wage treatment are compared with low-wage workers without the minimum wage treatment, we found the larger disemployment effect of minimum wage because of low-wage workers' stronger attachment to employment. We prefer the estimates in Table 5 to the estimates in Table 4 because low-wage workers are a more natural control group for the workers treated by the minimum wage. This result contrasts with the results obtained from the US and Canada; in those countries, low-wage workers are more likely to drop off from employment. We speculate that this is because we used female workers as a sample. High-wage female workers presumably have better marriage offers and may be more likely to drop out of the labor market, even after considering the fact that they receive a high wage.

The above estimation strategy may invite another criticism because the sample includes those workers who work for employers not complying with the minimum wage. Those who work for non-complying employers earn an 
even lower wage than those workers who are presumably treated by the minimum wage. Thus, those workers intrinsically may have a stronger attachment to employment than workers treated by the minimum wage. If this is the case, we may have overestimated the adverse effect of minimum wage on employment. To address this possibility, we further restrict our sample to those workers whose current wage is above the current minimum wage, but less than 110 percent of the current minimum wage. The results of the estimations based on this restricted sample B appear in Table 6. The results reported in Column (1) suggest that the results based on restricted sample A suffered from downward bias due to the fact that workers who receive less than the minimum wage have a stronger attachment to employment. However, once the sample is confined to workers who were included in restricted sample B for more than two years (i.e., the sample that can be used for random and fixed effects estimations), the estimated coefficient becomes about -0.2 with standard error of 0.11 , as reported in Column (2). The increase in the size of the coefficient in absolute value compared with Column (1) implies that the effect of minimum wage on employment was stronger among low-wage workers for more than 2 years in the sample. It is natural to expect that the effect of the minimum wage treatment would be more severe among "permanent" low wage workers because the sample used to estimate Column (1) may have included those temporary low wage workers for whom the effect of minimum wage treatment would be weak. This change of the results is similar to the change found in Yuen [2003]. 
Thus far, we have neglected the issue of panel attrition. If being affected by the minimum wage itself causes panel attrition, then our estimates may have been subject to attrition bias. However, we expect this bias to be minimal. Among 1505 observations in year $t-1,67$ observations dropped out of the sample in year $t$, as reported in Table 2 . To test for the systematic attrition due to the minimum wage treatment, we regressed the dummy variable indicating the panel attrition on the treatment dummy of minimum wage $\left(\right.$ bind $\left._{i, t-1}\right)$, along with other explanatory variables included in Tables 3 through 6 . The coefficient for this treatment dummy is 0.0175 with a standard error of 0.0568 . This result indicates that there is no systematic panel attrition due to the minimum wage treatment. As for the restricted samples $\mathrm{A}$ and $\mathrm{B}$, only one individual dropped out between years $t-1$ and $t$. Thus, we conclude that the issue of panel attrition is negligible.

\section{Conclusion}

We examined the impact of the minimum wage on employment in Japan, using data collected between 1993 and 1999. To estimate the effect, we compared the transition rate from employment to non-employment in a one-year window between two groups of workers. One of these groups consisted of workers whose wage was originally above the revised level of the minimum wage and therefore were not affected by the revision of the minimum wage. The other group consisted of workers whose wage was below the revised minimum wage and potentially was treated by the revision of the minimum wage. 
The estimation results based on the sample of low-wage workers indicate that workers in the latter group were about 20 percentage points less likely to be employed in the following year than those in the former group.

We should admit that we could not draw a definitive conclusion regarding the impact of the minimum wage on employment because of the small sample size. However, our results suggest the existence of a large disemployment effect in Japan, whose magnitude is comparable to that found in the US and Canada. Further study on this issue with larger government statistics is urgently needed, considering Japan's current, continuous deflation.

\section{References}

Yukiko Abe. The effect of regional minimum wage on the wage of part-time workers (chikibetu saitei tingin ga pat tingin ni ataeru eikyo). In Takenori Inoki and Fumio Ohtake, editors, An Economic Anlysis of Employment Policies in Japan (Koyo seisaku no keizai bunseki). University of Tokyo Press, 2001. in Japanese.

Takashi Araki. Labor and Employment Law in Japan. The Japan Insitute of Labor, 2002.

Charles Brown. Minimum wages, employment, and the distribution of income. In Orley Ashenfelter and David Card, editors, Handbook of Labor Economics Vol. 3. Elsevier, 1999.

David Card and Alan Krueger. Minimum wages and employment: A case 
study of the fast food industry in New Jersey and Pennsylvania. American Economic Review, 84(4):772-793, 1994.

David Card and Alan Krueger. Minimum wages and employment: A case study of the fast-food industry in New Jersey and Pennsylvania: Reply. American Economics Review, 90(5):1397-1420, 2000.

Janet Currie and Bruce C. Fallick. The minimum wage and the employment of youth: Evidence from the NLSY. Journal of Human Resources, 31(2): 404-428, 1996.

Miki Kohara. Who are supported by the minimum wage? (saitei chingin ha dare wo sasaeteiruka?). mimeo, Graduate Research Institute of Policy Studies, 2000.

Stephen Machin and Alan Manning. Minimum wages and economic outcomes in Europe. European Economic Review, 41(3-5):733-742, 1997.

Stephen Machin, Alan Manning, and Lupin Rahman. Where the minimum wage bites hard: The introduction of the uk national minimum wage to a low wage sector. Journal of European Economic Association, 1(1):154-180, 2003.

Nobuko Nagase. Why do part time workers earn low wage? Insititutional obstacles (pāt chingin ha naze hikuika? shoseido no ashikase). in Progress of globalization and the labor market - the effect of instituions and policies - by Institute for Statistical Research, 1997. 
David Neumark and Paul Taubman. Why do wage profiles slope upward? tests of the general human capital model. Journal of Labor Economics, 13 (4):736-761, 1995 .

David Neumark and William Wascher. Evidence on employment effects of minimum and subminimum wage: Panel data on state minimum laws. Industrial and Labor Relations Review, 46(1):55-81, 1992.

David Neumark and William Wascher. Minimum wages and employment: A case study of the fast-food industry in New Jersey and Pennsylvania: Comment. American Economic Review, 90(5):1362-1396, 2000.

David Neumark and William Wascher. Minimum wages, labor market institutions, and youth employment: A cross-national analysis. Indutrial and Labor Relations Review, 57(2):223-248, 2004.

OECD. Employment Outlook, chapter Chapter 2: Making the most of the minimum: statutory minimum wages, employment and poverty, pages $31-$ 79. Organisation for Economic Co-operation and Development, 1998.

Sonia Pereira. The impact of minimum wages on youth employment in Portugal. European Economic Review, 47(2):229-244, 2003.

Rōdō-Hōrei-Kyōkai. Wage Census, volume 3. Rōdō-Hōrei-Kyōkai, Each Year.

Kazuo Sugeno. Japanese Employment and Labor Law. Carolina Academic Press, 2002. 
Terence Yuen. The effect of minimum wages on youth employment in canada. Journal of Human Resources, 38(3):647-672, 2003. 
Table 1: Sample Selections

\begin{tabular}{lcc}
\multicolumn{1}{c}{ Selections } & Description & Number of Observations \\
\hline Raw data & & 10504 \\
Females who live in Japan & 10493 \\
$\begin{array}{l}\text { Workers who are paid on an hourly or } \\
\text { daily basis }\end{array}$ & 1924 \\
$\begin{array}{l}\text { Exclude missing values on wage, job } \\
\text { tenure, and years of experience }\end{array}$ & Control group and \\
Observed at both t-1 and t & treatment group & 1837 \\
$w_{i, t-1} \leqq 1.10 * m w_{i, t-1}$ & Sample A & 1438 \\
In sample A for more than two years & Sample A' & 236 \\
$m w_{i, t-1} \leqq w_{i, t-1} \leqq 1.10 * m w_{i, t-1}$ & Sample B & 152 \\
In sample B for more than two years & Sample B' & 148 \\
$m w_{i, t-1} \leqq w_{i, t-1} \leqq m w_{i, t}$ & Treatment group & 96 \\
\hline
\end{tabular}


Table 2: Sample Means

\begin{tabular}{|c|c|c|c|c|c|}
\hline \multirow{5}{*}{ Variables } & (1) & (2) & (3) & \multirow{5}{*}{$\begin{array}{c}\text { (4) } \\
\\
\begin{array}{c}\text { Treatment } \\
\text { group }\end{array} \\
\end{array}$} & \multirow{5}{*}{$\begin{array}{c}\text { (5) } \\
\text { Out of Sample in } \\
\text { Year } t\end{array}$} \\
\hline & \multicolumn{3}{|c|}{ In Sample in Year t } & & \\
\hline & \multirow{3}{*}{ Full Sample } & \multicolumn{2}{|c|}{ Control group } & & \\
\hline & & Sample A & Sample B & & \\
\hline & & $\left(\mathrm{w}_{\mathrm{i}, \mathrm{t}-1} \leqq 1.10 \mathrm{mw}_{\mathrm{i}, \mathrm{t}-1}\right)$ & $\left(\mathrm{mw}_{\mathrm{i}, \mathrm{t}-\mathrm{I}} \leqq \mathrm{w}_{\mathrm{i}, \mathrm{t}-1} \leq 1.10 \mathrm{mw}_{\mathrm{i}, \mathrm{t}-1}\right)$ & & \\
\hline Employment $_{\mathrm{it}}$ & 0.837 & 0.876 & 0.869 & 0.722 & \\
\hline \multicolumn{6}{|l|}{ Characteristics in Year t-1 } \\
\hline Hourly wage & 900.57 & 624.55 & 646.05 & 618.75 & 878.27 \\
\hline Daily wage & 6507.9 & 4097.81 & 5060.1 & 4879.7 & 7260.0 \\
\hline Married & 0.717 & 0.812 & 0.823 & 0.722 & 0.642 \\
\hline Number of children & 1.231 & 1.541 & 1.492 & 1.278 & 0.986 \\
\hline Age & 31.46 & 31.66 & 31.66 & 31.83 & 30.00 \\
\hline Job tenure & 2.152 & 2.318 & 1.966 & 3.986 & 2.290 \\
\hline Years of experience & 9.155 & 8.857 & 8.608 & 7.653 & 7.719 \\
\hline \multicolumn{6}{|l|}{ Educational background: } \\
\hline Junior or technical college (14 years) & 0.200 & 0.165 & 0.192 & 0.278 & 0.119 \\
\hline Career college (14 years) & 0.180 & 0.133 & 0.131 & 0.056 & 0.239 \\
\hline High school (12 years) & 0.522 & 0.651 & 0.623 & 0.556 & 0.522 \\
\hline Junior high school (9 years) & 0.020 & 0.028 & 0.038 & 0.000 & 0.045 \\
\hline Other & 0.004 & 0.000 & 0.000 & 0.056 & 0.000 \\
\hline \multicolumn{6}{|l|}{ City size: } \\
\hline 13 large cities & 0.234 & 0.147 & 0.123 & 0.111 & 0.284 \\
\hline Other cities & 0.549 & 0.555 & 0.669 & 0.722 & 0.433 \\
\hline Towns or villages & 0.217 & 0.298 & 0.208 & 0.167 & 0.284 \\
\hline Number of Observations & 1420 & 218 & 130 & 18 & 67 \\
\hline
\end{tabular}

Notes: The sample includes the 1171 female workers who were paid on an hourly basis and the 267 female workers who were paid on a daily basis. The dummy variable, employment $t_{i t}$, equals one if the respondent was employed during year $t$ and zero if she was not employed during year $t$. 
Table 3: The Effects of the Minimum Wage on the Change of Wage

Ordinary Least Squares; Dependent Variable: $\log$ wage $_{i t}-\log$ wage $_{i, t-\tau}$

\begin{tabular}{cccc}
\hline & $(1)$ & $(2)$ & $(3)$ \\
\cline { 2 - 4 } Explanatory Variables & Control group & Restricted sample A & Restricted sample B \\
\hline bind $_{i,-1}$ & 0.0413 & 0.0168 & 0.0231 \\
& $(0.0425)$ & $(0.0612)$ & $(0.0580)$ \\
\hline Number of Observations & 963 & 151 & 106
\end{tabular}

Notes: Clustering robust standard errors are in parentheses. The sample includes female hourly and daily workers who were employed during year t. Other explanatory variables in the estimation models are an intercept, age, the number of children, and the dummy variables of year, prefecture, marital status, and education.

Table 4: The Effects of the Minimum Wage on Employment

Dependent Variable: employment ${ }_{i t}$

\begin{tabular}{lcccc}
\hline & $(1)$ & $(2)$ & $(3)$ & $(4)$ \\
\cline { 2 - 5 } Explanatory Variables & OLS & OLS & $\begin{array}{c}\text { Random } \\
\text { Effects }\end{array}$ & Fixed Effects \\
\hline \multicolumn{1}{c}{ bind $_{i, t-1}$} & -0.1097 & -0.0414 & -0.0613 & -0.1153 \\
& $(0.0887)$ & $(0.0828)$ & {$[0.0844]$} & {$[0.1013]$} \\
\hline Number of Observations & 1438 & 1213 & 1213 & 1213 \\
\hline $\begin{array}{l}\text { Notes: } \text { Clustering robust standard errors and Huber-White standard errors are in parentheses and } \\
\text { square brackets, respectively. The sample includes female hourly and daily workers who were }\end{array}$ \\
employed during year t. Other explanatory variables in the estimation models are an intercept, \\
age, the number of children, and the dummy variables of year, prefecture, marital status, and \\
education.
\end{tabular}

Table 5: The Effects of the Minimum Wage on Employment, Restricted Sample A

Dependent Variable: employment ${ }_{i t}$

\begin{tabular}{ccccc}
\hline & $(1)$ & $(2)$ & $(3)$ & $(4)$ \\
\cline { 2 - 5 } Explanatory Variables & \multirow{2}{*}{ OLS } & OLS & $\begin{array}{c}\text { Random } \\
\text { Effects }\end{array}$ & Fixed Effects \\
\hline bind $_{i, t-1}$ & -0.1504 & -0.1449 & -0.1654 & -0.2257 \\
\hline Number of Observations & $(0.0925)$ & $(0.0858)$ & {$[0.0825]$} & {$[0.1272]$} \\
\hline
\end{tabular}

Notes: The same note applies as in Table 4

Table 6: The Effects of the Minimum Wage on Employment, Restricted Sample B

Dependent Variable: employment ${ }_{i t}$

\begin{tabular}{ccccc}
\hline & $(1)$ & $(2)$ & $(3)$ & $(4)$ \\
\cline { 2 - 5 } Explanatory Variables & OLS & OLS & $\begin{array}{c}\text { Random } \\
\text { Effects }\end{array}$ & Fixed Effects \\
\hline bind $_{i, t-1}$ & -0.0782 & -0.2173 & -0.2362 & -0.4023 \\
Number of Observations & $(0.1025)$ & $(0.1111)$ & $(0.0932)$ & $(0.1436)$ \\
\hline Notes: Thery & 148 & 96 & 96 & 96 \\
\hline
\end{tabular}

Notes: The same note applies as in Table 4 
Figure 1

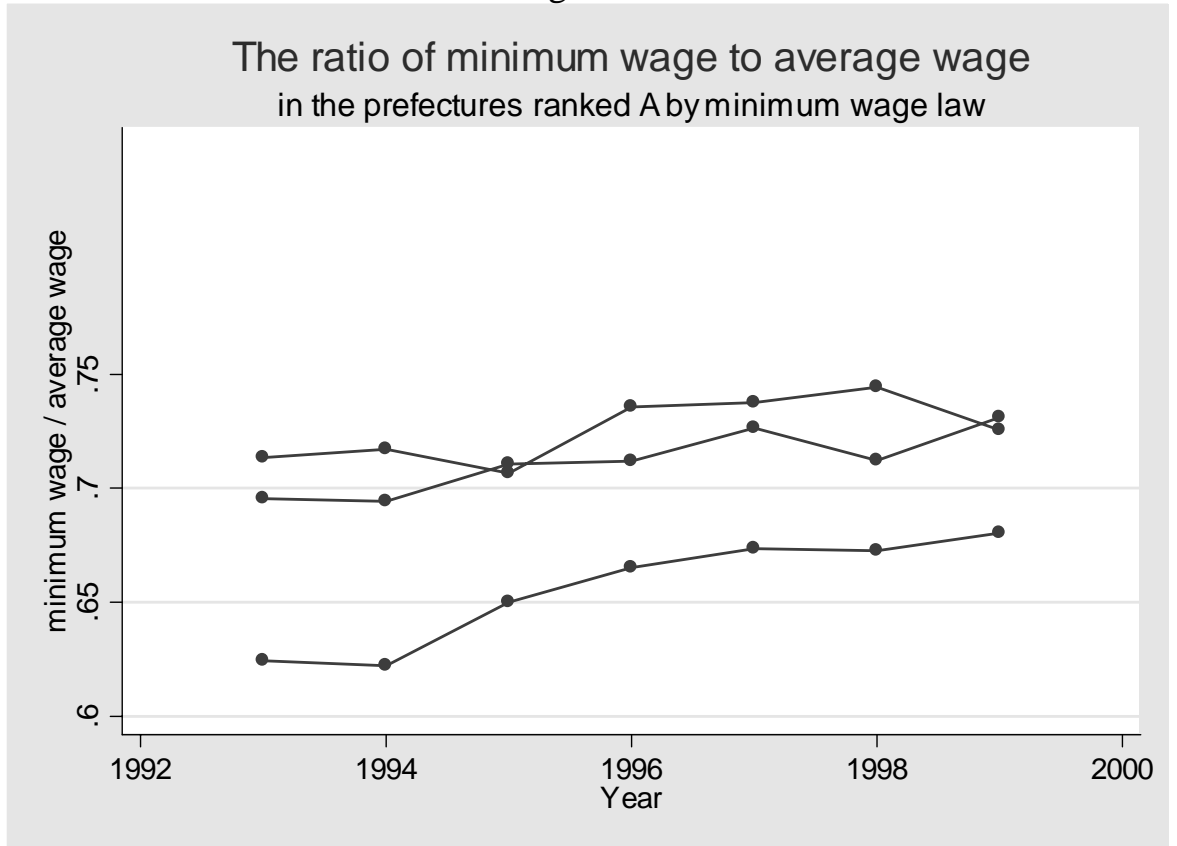

Figure 2

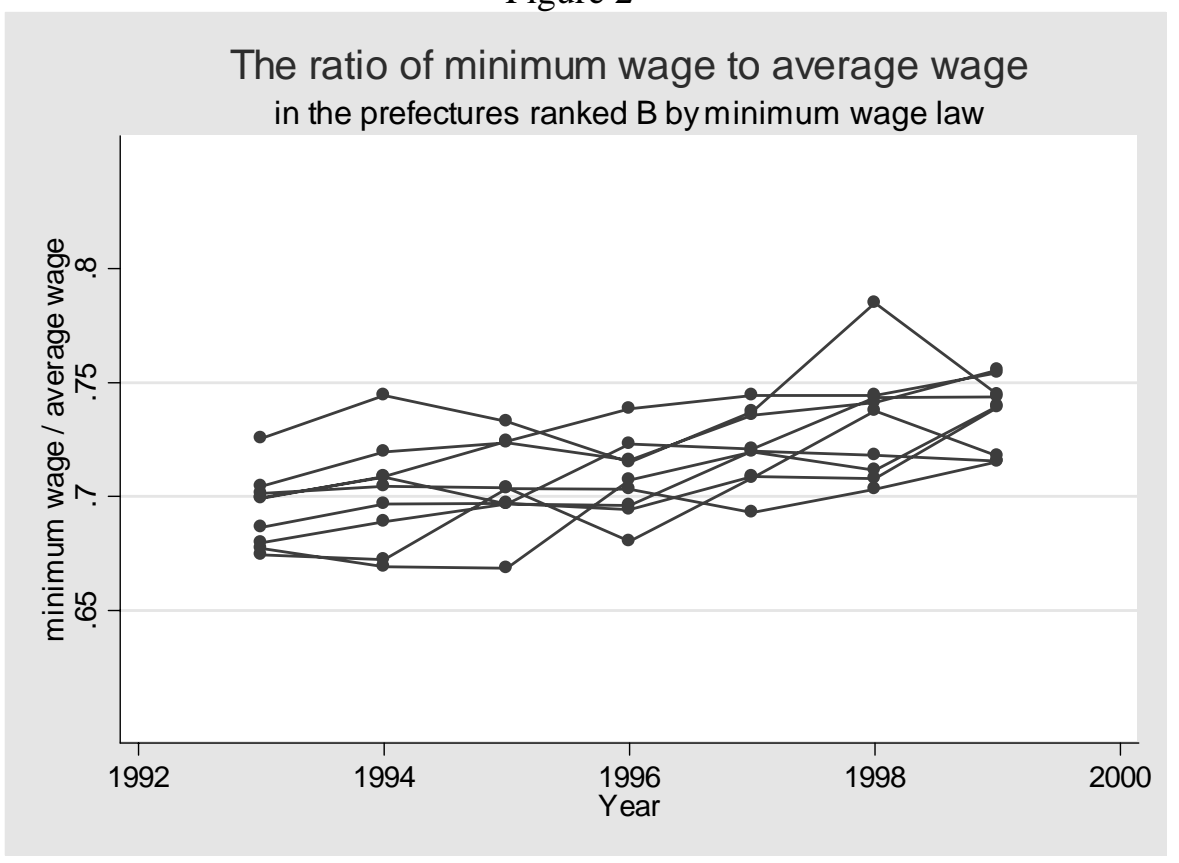


Figure 3

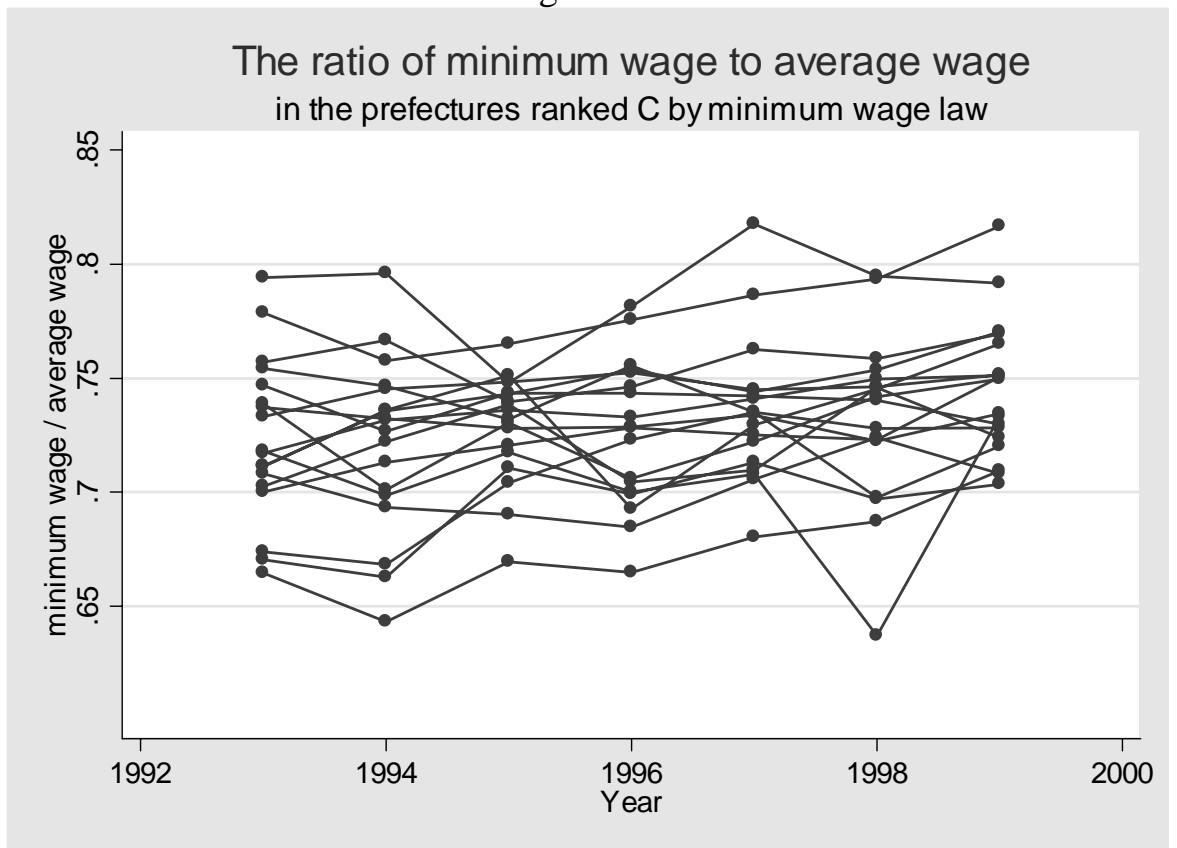

Figure 4

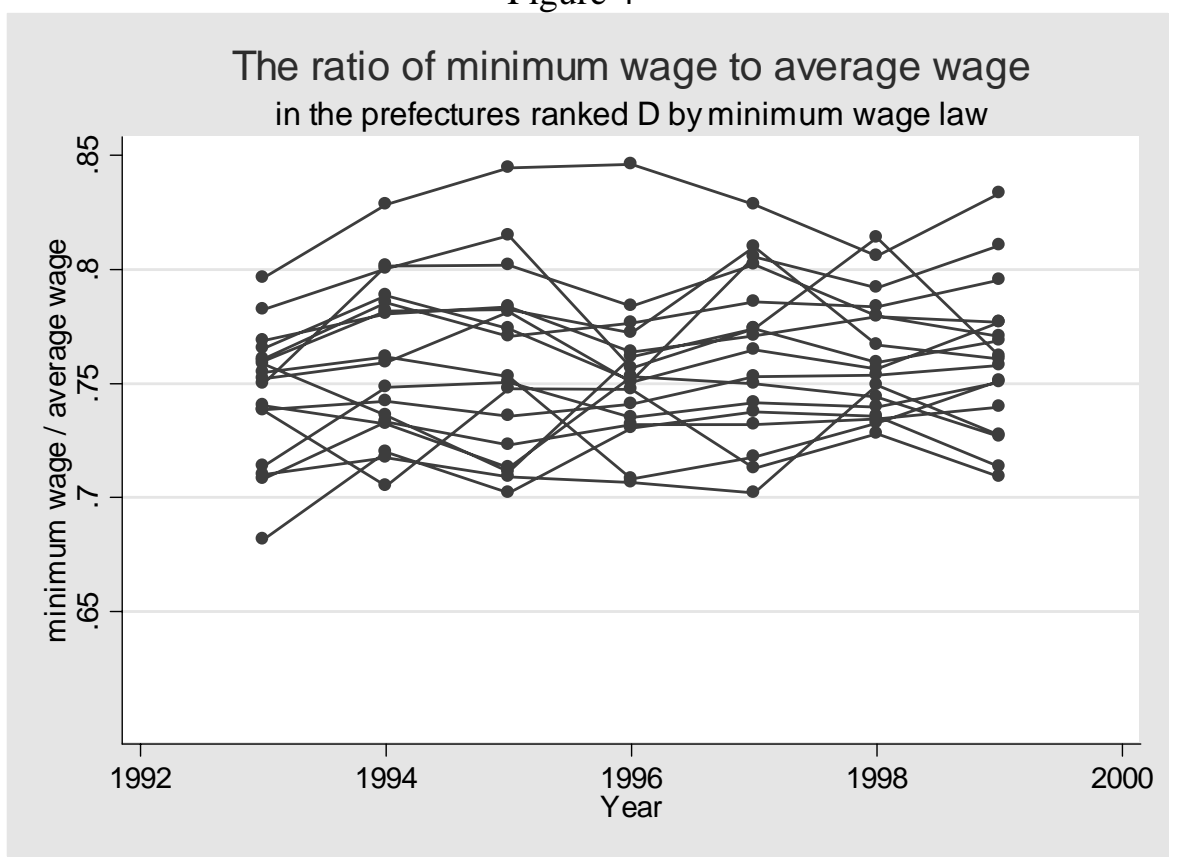

